Зона В. МРКАљ*

Универзитет у Београду

Филолошки факултет
Оригинални научни рад

Примљен: 11. 12. 2017.

Прихваћен: 27. 12. 2017.

\title{
НАЧИНИ УПОТРЕБЕ РЕЧНИКА СРПСКОГ ЈЕЗИКА У НАСТАВИ СРПСКОГ ЈЕЗИКА И КЬИЖЕВНОСТИ
}

\begin{abstract}
У раду се разматра који речници српског језика се препоручују за коришћење у настави српског језика и књижевности.

Указује се на различите начине употребе речника: а) у редовној настави књижевности, уз помоћ методичке радње тумачење непознатих и мање познатих речи и израза, приликом интерпретације књижевноуметничких текстова; б) у редовној настави језика, уз конкретне наставне јединице, нпр.: историзми, архаизми, неологизми, жаргонизми...; в) у раду лингвистичке секције - по узору на постојеће речнике ученици стварају речнике на задате теме (нпр. Речник непознатих и мање познатих речи уз дело Живот и прикљученија Доситеја Обрадовића); г) на часовима усменог и писменог изражавања, са циљем даљег богаћења ученичког речника; д) приликом усавршавања вештине читања и разумевања прочитаног, где се посебна пажња обраћа на контекст и вишезначност појединих речи, као и на њихову стилску улогу; ђ) на часовима српског језика у школској библиотеци - где се ученици непосредно упознају са изгледом и различитим типовима речника, као и са начином њиховог коришћења.
\end{abstract}

Кључне речи: речници, настава, српски језик, књижевност, непознате речи, лингвистичка секција, школска библиотека.

Употреба речника у настави српског језика и књижевности најчешће се везује за методичку радњу тумачење непознатих и мање познатих речи $u$ израза. Начини тумачења ученицима непознатих речи веома су различити и зависе од природе наставне јединице која се обрађује. Приликом припремања за интерпретацију књижевноуметничког текста (у оквиру задатака за истраживачко читање), а најчешће после наставниковог читања предвиђеног одломка на часу, ученик бива подстакнут да издвоји речи чија значења му нису сасвим јасна, да потражи њихово тумачење у неком од речника, или покуша да докучи њихов смисао из контекста. Овај други, нешто спорији на-

\footnotetext{
*mrkalj@ikomline.net
} 
чин бављења речима, доприноси утемељивању принципа свесне активности ученика, што захтева активан однос према читању и учењу, али не мора увек донети поуздане резултате.

Савремене читанке помажу ученицима да до значења претпостављених непознатих речи лакше дођу. Навођена после текста или на маргинама уџбеника (паралелно с текстом где се те речи јављају), значења речи најчешће се дају описно и у вези са њиховом конкретном појавом у тексту, а ређе се наводи шта све једна реч може да значи. Разлог за то углавном је недостатак простора за увођење ширих, целовитих објашњења (читанке су ограниченог броја страница, у зависности од узраста ученика), мада, према важећем Закону о уџбеницима, читанке морају да садрже и речник на крају књиге. Већ овде може се проблематизовати шта је све обавезно да уђе у тај речник. Мада су многи књижевнотеоријски и књижевноисторијски појмови објашњени у читанкама и наведени у индексу појмова, и они су на одређени начин за ученике непознате или мање познате речи.

Поједини издавачи (нарочито у издањима за млађе разреде) прибегавају коришћењу илустрација приликом објашњавања одређених речи, чиме се ученик (у складу с применом метода показивања) визуелно подстиче да себи растумачи пре свега изглед, а онда и сврху неког предмета или појаве.

Вишедеценијско искуство у непосредној настави у основној или средњој школи и на часовима хоспитовања у београдским школама показало је да наставници веома ретко ученике упућују на коришћење речника српског језика, или, ако то и учине, немају времена да сваком ђаку покажу и објасне поједине речничке одреднице.То, евентуално, чине библиотекари, уколико им се пружи прилика, па многи ученици још увек не знају ни како речници српског језика изгледају, а још мање су обавештени о значењу скраћеница у њима. Речници страних језика се знатно више користе.

Методичку радњу тумачења непознатих и мање познатих речи погрешно је изводити у блоку, након читања. Објашњења која дају и ученици и наставници саставни су део интерпретације. Зато је недопустиво подилажење ученицима путем тзв. адаптираних текстова у којима се, на пример, архаизми замењују одговарајућим новим речима, а остали мање познати појмови фреквентнијим синонимима. Површно читање и аутоматско разумевање прочитаног, без креативних застајања и запитаности, свакако неће помоћи развијању љубави према књизи. Ова активност се као стилска или лексичка вежба може остварити, али тек након читања и разумевања оригиналног текста.

Међу заговорницима потребе да се оригинални књижевни текстови замене адаптираним, највише има оних који тврде да је наша народна књижевност потпуно неразумљива младима. Један од начина да се овај проблем премости јесте задавање занимљивих задатака у вези са непознатим речима и идиомима, чије решавање ће допринети функционализацији ученичког знања.

1. „Прочитајте објашњења речи јеленак и разбој у Вуковом Српском рјечнику. Шта данас значе ови појмови? 
2. Проучите из Рјечника како су се некада играле игре купа, клас и провођач. Опишите и именујте једну занимљиву игру које се сећате из детињства.

3. Да ли бисте волели да имате расковник? У које сврхе бисте га користили?

4. Забележите што више речи којима се данас именују родбинске везе. Притом се потрудите да у ваш избор уђу и речи: јетрва, заова, нећак, пашеног итд." (Мркаљ 2008: 110).

5. Писмено објасните значења фразеологизама с компонентом глава: увртети себи у главу; изаћи на врх главе; чувати као очи у глави; мућнути главом; напунити главу; климати главом; имати што у глави; имати дивљи (луди) ветар у глави (в. Мршевић-Радовић 2008: 106-109); пробити главу; памет у главу; носити главу у торби; претурати по глави; с главе риба смрди; није о главу итд.

Са тумачењем непознатих речи, појмова и израза ученици се сусрећу приликом сваког приступа књижевном делу у настави. Обим непознатих речи условљен је природом текста који се обрађује, а њихово тумачење усклађује се и са конкретним радним околностима, узрастом, предзнањима и способностима ученика. Уобичајено је да се непознате речи тумаче већ у припремној фази када их има много или када битно условљавају целовит доживљај и разумевање дела. Најфункционалније је непознате речи тумачити у свакој радној околности коју наставник процени као повољну након читања, односно током тумачења, уколико ученици укажу да су им поједини језички садржаји у делу непознати или нејасни. Ипак, претерано одлагање тумачења непознатих речи може да демотивише рад ученика, угрози разумевање дела и читалачке доживљаје умањи, те да се негативно одрази и на тумачење. Зато је управо наставник тај који одређује динамику тумачења и усвајања нових речи, пре свега у циљу богаћења ученичког речника.

Континуиран рад на тумачењу непознатих речи доприноси развијању способности умећа ученика да ову активност временом почну да обављају као саморадњу. Уместо уобичајеног и мање продуктивног захтева у оквиру задатака за истраживачко читање Пронађи и протумачи непознате речи из текста, може се поступити и овако:

„Пажљиво прочитај шаљиву народну причу Еро и кадија. Запази у каквом су односу два насловна лика у причи. Уочи чија је крава страдала када се марва побола. Примећујеш да Еро одлази кадији да овај пресуди. Како се данас зове човек који доноси пресуде? Зашто га Еро ословљава и с ефендија? Како му се уместо тога могао обратити? Образложи зашто кадија каже да марви нема суда. Ко је марва? Зашто се животињама не може судити?

Размотри у ком тренутку се кадија ипак решава да погледа у ћuтаn. Покушај по смислу приче да одредиш шта је ћитап. По чему закључујеш да је то нека важна књига? Како Еро реагује кад кадија хоће да погледа у ћитап? Шта мислиш, шта у таквој књизи пише? Истакни у чему се све огледа Ерина мудрост и домишљатост у овој причи” (Мркаљ 2008: 111). 
Савремени образовни систем Републике Србије подразумева да се ученици припремају да досегну веома захтевне стандарде, који представљају описе ученичких постигнућа на одређеном нивоу. Овде наводимо два исхода и читав низ стандарда чијем остваривању се тежи приликом обраде наставне јединице: Архаизми, историзми, неологизми, жаргонизми и вулгаризми у трећем разреду средњих стручних школа и гимназија.

Исходи: Ученик уме да препозна и одреди вредност лексеме. Разуме и наводи синониме за архаизме, неологизме, жаргонизме и вулгаризме у складу са књижевним језиком.

Стандарди: Ученик има лексички фонд који је у складу са средњим нивоом образовања; Прави разлику између формалне и неформалне лексике и употребљава их у складу са приликом; Нема одбојност према речима страног порекла, али их не прихвата некритички и аутоматски; Препознаје конотативно значење речи у датом контексту; Одређује значење непознате речи на основу контекста и творбеног модела; Познаје одлике варијетета српског језика који су условљени социјално и функционално; Има богат и разнолик лексички фонд који употребљава у складу с приликом; Има основна знања о речницима итд. (в. Општи стандарди 2015).

Овде се поставља питање која су то основна знања о речницима, односно, шта то један средњошколац има као обавезу да током средње школе о речницима научи. ${ }^{1}$

Да би се колико-толико приближило овим захтевним стандардима, потребно је дефинисати циљеве часа, тј. шта заправо желимо да остваримо за 45 минута, и прецизирати на који начин ће коришћење речника ученицима помоћи да остваре планирано и усвоје нови наставни садржај.

Наставник, након објашњавања појмова који су тема часа, уз мноштво одабраних примера који се бележе на табли, дели припремљене наставне листиће на којима се могу наћи следећи примери, уз претходно дат налог:

Пажљиво прочитајте дате реченице. Одредите који је тип речи (мисли се на архаизме, историзме, неологизме, жаргонизме ${ }^{2}$ и вулгаризме) најзаступљенији и подвуците те речи. Размислите о имену своје групе, у оквиру које ћете заједно радити.

1. Кад су алас и видар пошли на војну, ћесар је већ био женик, а јуноша је још читао писменицу.

2. Заробљени дијак и пехарник из пашалука надомак некадашње Аустроугарске молили су дужда да талирима плате своју слободу.

\footnotetext{
${ }^{1}$ На часовима српског језика ученици се упознају са различитим типовима речника:

Фреквенцијски речници - представљају анализу најфреквентније лексике неког писца (на пример, Смиљка Васић, Фреквенцијски речник романа Бездно Светлане Велмар-Јанковић);

Деривациони речници - указују на лексички потенцијал језика кроз настанак нових речи (Мирослав Николић, Обратни речник српског језика);

Речници страних речи - објашњавају значење позајмљеница (Милан Вујаклија, Лексикон страних речи и израза);

Етимолошки речници - објашњавају порекло речи (Петар Скок, Етимологијски рјечник хрватскога или српскога језика) итд.

${ }^{2}$ Наставник упућује ученике на коришћење речника жаргона, што ученици воле да читају и истражују са занимањем. (На пример, Андрић 1976).
} 
3. Данас у самопослугама продају замрзиваче и мини-сукње. Пишем блог о лаптоповима и ајподима.

4. Јуче сам на Зелењаку срео једног лика. Пришао је и почео да ме смара. Рекао је да ради као физикалац, а хоће да сними неки народњак и постане фаца.

5. Успео сам да зезнем Марка. Увалио сам му пробушену амбалажу и сав се усвињио. Шлихта ми се она битанга што шљока.

За употребу, коришћење и примену речника ученици се обучавају благовремено и навикавају поступно, континуирано и систематично, а најфункционалније тако што се речници, њихови садржаји и употреба упознају у радном садејству обраде књижевног дела и одговарајућих наставних садржаја из области језика. На пример, обрадом одабраних одломака из Вуковог Српског рјечника из 1852. године ученици су у прилици да упознају изворно лексикографско штиво, те да том приликом стекну знања о речничким чланцима, да разликују лему и податке о речима, лексикографски поступак приликом тумачења речи и описе који је прате. Том приликом ученици усвајају функционалне појмове из области лексикологије и лексикографије, схватају њихов смисао, значај и методолошке поступке којима се речи приказују и тумаче у речницима.

Добро је ученике упутити на издања репрезентативних речника српског језика, а највише на Речник српскохрватскога книжевног језика (1967-1976), Речник српскохрватског книжевног и народног језика (1959-), Обратни речник српскога језика (2000) и Речник српскога језика (2007) као поуздане лексикографске изворе српског језика. Било би добро да се у наставу и рад укључују и други одговарајући речници, као што су Рјечник хрватскога или српскога језика Југославенске академије знаности и умјетности (1880-1976) различити фреквенцијски речници српског језика, асоцијативни речници и речници синонима, али је њихова доступност у школским библиотекама, посебно у мањим срединама, врло слаба. Наставник најчешће мора да посредује у употреби ових издања тако што одговарајуће садржаје користи током свог припремног рада и упућује их ученицима. Нешто већа је доступност других речника који квалитетно тумаче лексикографску грађу, а у школским условима могу бити од користи. ${ }^{4}$

Приликом рада на текстовима различитог типа, непозната реч појављује се у тексту дела на више начина: она ученицима може бити непозната и по облику и по значењу, може им бити позната реч, али не и појам који је њоме означен, а значење речи може бити непознато, односно нејасно у контексту услед вишезначности или фигуративне употребе језика (према: Николић 2009: 302). Запажено је да се основна значења речи у контексту дела мењају или модификују, у складу са стилском обрадом, али и у тим ситуацијама тре-

\footnotetext{
${ }^{3}$ Ово је једини историјски речник српског (и хрватског) језика који обухвата грађу од најстаријих споменика до данас.

${ }^{4}$ Такви су, између осталих, следећи речници: (Клајн 1992), (Клајн/Шипка 2008), (Ћирилов 1991), (Вујаклија 1991), (Стефановић/Пипер/Драгићевић 2011).
} 
ба поћи од примарног значења речи, а онда навикавати ученике да у складу са контекстом одгонетају лексичка значења у тексту конкретног дела. Значења која појединим речима дају писци у стваралачкој обради кореспондирају са примарним или полазним значењима речи, те је пожељно најпре консултовати речнике књижевног језика (в. Цвијетић 2005: 63-72).

Успешна истраживања којима се подстиче коришћење различитих типова речника у настави најчешће се спроводе у оквиру рада лингвистичких секција, са ученицима који су посебно заинтересовани за овакве активности. Овде помињемо изузетне резултате које су постигли ученици седмог разреда основних школа из Београда, правећи речник непознатих и мање познатих речи из Живота и прикљученија Доситеја Обрадовића (видети Прилог 1), у оквиру Радионище језикословаиа (коју је организовала Задужбина „Доситеј Обрадовић”). Могућности коришћења речника српског језика су бројне, као и изазови који се постављају пред ученике и наставнике, не само кад је реч о народној књижевности, средњовековној књижевности, књижевности ренесансе, рационализма или романтизма, већ и онда кад се читају дела реалиста и савремених писаца (на пример, Сремчеве приповетке и романи, или реплике Енглескиње из Селенићевог романа Очеви и оии).

У многим делима школске или домаће лектире, делимично или у целини, појављују се регионализми, дијалектизми, жаргонизми, идиолекти и нестандардни језички варијетети. У романима неких аутора читав приповедачки поступак остварен је неким од нестандардних језичких варијетета, какви су, на пример, Петријин венаи и Кад су иветале тикве Драгослава Михаиловића. Конкретне радне околности такође се уважавају приликом обраде оваквих дела. Поменуте лексичке појаве није пожељно објашњавати записивањем нити обимним тумачењем, већ економисати наставним временом посредством најкраћих усмених објашњења пошто је реч о лексици за коју се не планира да је ученици активно користе.

Ипак, записана тумачења непознатих речи и појмова била би ученицима од користи као приручни радни речник који ће они током самосталног читања лектире допуњавати. Непосредним упознавањем методологије којом ће се речи тумачити током читања књижевних текстова, ученици се функцинално обучавају за остваривање ове радње, а истовремено се уводе у поетику и свет конкретног дела које ће истраживачки и доживљајно потом у целини читати уз тумачење језичких непознаница.

Непознате речи, поред коришћења речника књижевног језика, речника нових речи и помоћи наставника ученици могу да тумаче и уз помоћ квалитетног примарног издања дела. Зато је корисно да наставник проучи издања књижевних дела која су у конкретним радним околностима доступна ученицима, те да им укаже на она која су добра и чијим коришћењем могу да упознају карактеристичну лексику у делу. У већини издања школске лектире речници непознатих речи су селективни и махом једнозначно протумачени. Врло често се не тумаче управо речи чије значење је ученицима најмање познато, док се објашњавају лексички садржаји који су, према мишљењима ученика, општепознати. Добро протумачена реч увек се објашњава посред- 
ством више одговарајућих синонима како би је ученици целовито разумели, а најбољи ефекат постиже се уколико се непознате речи, а посебно појмови, тумаче описно, односно проширено.

Примарни извори за тумачење дела у којима је тумачење непознатих или мање познатих речи остварено на стручно квалитетан и технички погодан начин, додатно мотивишу ученике за читање, доживљавање и тумачење дела. Роман Бранислава Нушића Аутобиографија (из едиције Пустоловине ИК „Креативни центар”) у целини је пропраћен тумачењем непознатих речи које се приказују напоредо са текстом дела, на широким маргинама књиге, па се тумаче усаглашено са текстом дела, а захваљујући подесном типографском облику и величини слова се лако издвајају и уочавају у односу на основни текст дела (Нушић 2001). Тумачење језичких садржаја у овом издању обухвата архаизме, речи страног порекла, историзме, али и појмове и појаве за које се претпоставља да су читаоцима непознате или да их мање поуздано познају. Протумачени су идиоми и фраземи у контексту дела, али се води рачуна и о томе да ученици у савременом језичком контексту упознају њихово значење. Већ на самом почетку дела читаоцима књиге се омогућава да упознају значење термина аутобиографија и биографија. Тиме се стварају повољности за истраживачки приступ значењским аспектима наслова романа. Повремено се тумачење непознатих речи и појмова у овом издању трансформише у мали енциклопедијски изворник јер су ученицима у примереној дужини саопштени подаци о личностима и прототипским појавама из света дела. Објављене су, између осталих, и краће биографије Кристифора Колумба, Јулија Цезара и Жила Верна, а читаоци се информишу о старословенском језику, Питагорином правилу, Александријској библиотеци. Издање књиге указује на сазнајну димензију романа и постаје извор знања. Ученици се могу подстаћи да, на пример, запазе које је изворно значење речи бакалин и упоређују га са савременом употребом ове речи и њених изведеница. Добро је и то што су поред тумачења појединих речи које означавају предмете који се не налазе у активној употреби (чигра, на пример, или таблица са сунђером и писаљком на којој су се ученици основних школа из Нушићевог доба учили писању) објављени цртежи или фотографије, па их ученици могу чулно актуелизовати и поуздано упознати.

Понекад је употреба појединих речи у делу фреквентна, али и значајна за разумевање кључних појединости, па је добро да наставник овакве лексеме протумачи већ током припремне фазе рада. На пример, у Робинсону Крусоу насловни јунак често помиње реч провиђење, позива се на њу, изговара је у кључним сценама, а посебно приликом размишљања о свему што доживљава. Провиђењем Крусо веома често тумачи свој опстанак, али и дешавања која су га довела у необичне ситуације. Овим појмом Дефо у знатној мери мотивише дешавања у делу тако да оно што је невероватно и немогуће приказује као вероватно и уверљиво. Наставник ће на ову посебност указати ученицима тако што ће им најпре уочи читања дела указати на заступљеност речи провиђење и мотивисати их да уочавају делове текста и садржаје из дела у којима се она појачано употребљава. Затим ће уз помоћ Речника сpnc- 
кохрватскога књижевног језика протумачити да је провиђење (провидност) реч којом се у религијском схватању означава деловање врховног, натприродног божанског бића. Понекад се само божанство именује овом речју (што се најчешће истиче писањем са великим почетним словом), а неретко се употребљава и синоним примисао.

У упутствима за читање дела наставник ће подстицати ученике да запажену реч и њену употребу повезују са проучавањем мотивације и уверљивости приказиваних дешавања у Дефоовом роману. Током тумачења установиће се да се провиђењем најчешће мотивишу невероватност обрта и збивања у којима Робинсон преживи бродолом, излечи се од болести, успе да се домогне дома и умакне налету чопора вукова приликом путовања кроз Европу до родне Енглеске. Провиђењем се, међутим, манифестује и већинска верска и друштвена идеологија Дефоовог доба.

Претерано одлагање тумачења непознатих речи као и учестало прекидање разговора о делу ради објашњавања мање познатих речи и појмова може да демотивише рад ученика, угрози разумевање дела и читалачке доживљаје умањи, те да се негативно одрази и на наставну интерпретацију. Зато је управо наставник тај који одређује динамику тумачења и усвајања нових речи, пре свега у циљу богаћења ученичког речника.

Школска библиотека је право место за окупљање ученика, заинтересованих за истраживачки рад у оквиру додатне наставе и секција. У библиотеци су ученицима здружено доступни примерци актуелних граматика, правописа, речника, језичких практикума или књига из историје језика, као и различите збирке задатака; многа стручна литература, часописи и енциклопедије за децу, интернет...

Како је библиотека и место где се ученици окупљају и креативно друже, пре свега с књигама, библиотекар ће подстицати младе кориснике у њиховим индивидуалним напорима да истраже литературу која ће им помоћи у решавању одређених проблема на које наилазе у припремању за редовну наставу и ваннаставне активности и упућивати их да самостално приступе решавању тих проблема. Ова врста комуникације допринеће остваривању многих функционалних циљева наставе српског језика, а ученицима ће бити пружена додатна могућност да се ослоне на још једног стручњака, поред предметног наставника, који ће им помоћи да правилним коришћењем различитих типова речника српског језика усаврше своју вештину читања и разумевања прочитаног и обогате свој речник. 
Прилог 1 - Радионица језикословаца ${ }^{5}$ - резултат рада лингвистичке секције

Живот и прикљученија Димитрија Обрадовича, нареченога у калуђерству Доситеја, ьим истим списат и издат (рад на одломцима)

Речник непознатих и мање познатих речи

\begin{tabular}{|l|l|l|}
\hline \multicolumn{1}{|c|}{ РЕЧ } & \multicolumn{1}{|c|}{ ЗНАЧЕњЕ } & \multicolumn{1}{|c|}{ ПРИМЕР } \\
\hline \multicolumn{1}{|c|}{ А } & \multicolumn{1}{|c|}{$\begin{array}{l}\text { П. јагъе } \\
\text { 2. фиг. кротак, безазлен човек }\end{array}$} & $\begin{array}{l}\text { 1. А ви, високопречасни, баш мислите да ја само онако блејим, у ветар, као } \\
\text { агнец. (РМС, 1, 45) } \\
\text { 2. Благи Спаситељ ни на што тако није се срдио, кротки божји агнец ни на } \\
\text { што тако није се гневио колико на сујеверје, на лицемерије и на лажљиву } \\
\text { и притворну светињу. (119) }\end{array}$ \\
\hline акатист м & похвална песма, ирквена молитва & $\begin{array}{l}\text { Мој је сав посао био држати чисто ћелију старца мога, очитати му који } \\
\text { акатист и канон и у трапези житије. (122) }\end{array}$ \\
\hline
\end{tabular}

${ }^{5}$ Најбољи рад у Радионици језикословаца, при Задужбини „Доситеј Обрадовић” (видети: www.dositejeva-zaduzbina.rs), био је рад ученика Основне школе „Михајло Пупин” у Земуну. У групи су се нашли: Наталија Ђорђевић, Дејана Марковић, Данило Мирјанић и Сара Ивановић, тада ученици седмог разреда. Ђихов ментор била је професорка српског језика Софка Радојичић. Овде се наводи само почетни део речника који су ученици саставили.

На почетку прављења речника задатак ученика је био да издвоје реченице или делове реченица у којима се налазе речи за које сматрају да их треба објаснити вршњацима. Објашњења значења речи ученици су проналазили у неколико различитих издања дела Живот и прикљученија, а највише информација о непознатим речима прикупили су листајући у библиотеци Речник српскохрватског књижевног и народног језика и Речник српскохрватскога књижевног језика.

Међу примерима (у целовитом речнику) налази се и неколико оних који су преузети из Речника српскохрватског кьижевног и народног језика (РСАНУ) и Речника српскохрватскога кьижсевног језика (PMC), да би се илустровала различита значења одређене речи. На пример: реч камара може да означава и собу, али и гомилу (хрпу); јуност је и младост и омладина, а кофета може бити и слаткии.

Иако се Доситеј залагао за писање књижевних дела на народном језику, у његовим делима ученици су препознали знатан број речи из рускословенског, црквенословенског и руског језика. С обзиром на то да су све ово словенски језици као и српски језик, ученицима је управо та делимична сличност са српским језиком сметала да разумеју право значење одређене речи. Тако су се сусрели и са међујезичком паронимијом (реч вредан може значити и штетан). Запазили су и да међу непознатим речима наведеним у овом речнику има доста и оних из класичних језика, као и из турског, француског, италијанског итд. 


\begin{tabular}{|c|c|c|}
\hline алфавит духовни & црквена књига & $\begin{array}{l}\text { Нађем зборник, часловац, псалтир, месецослов, каноник, полустав, треб- } \\
\text { ник, алфавит духовни. (117) }\end{array}$ \\
\hline алфавит м & $\begin{array}{l}\text { алфабет, ред слова у грчкој азбуии, } \\
\text { буквица, азбука, абецеда }\end{array}$ & Нека уђе онај који је по алфавиту први. (РМС, 1,71$)$ \\
\hline анатема ж & $\begin{array}{l}\text { чин којим се неко одлучује од иркве; } \\
\text { проклетство; } \\
\text { фиг. клетва, оштра осуда }\end{array}$ & $\begin{array}{l}\text { У истој књиги читао си ми шта га су пута неки сабори од пет и шест сто- } \\
\text { тина отаца неке ствари узаконили и утврдили... јоште к тому да у самом } \\
\text { Цариграду било је више од двадесет и седам сабора који су проклетству и } \\
\text { анатеми предати. (124) }\end{array}$ \\
\hline антипод м & $\begin{array}{l}\text { фиг. оно штоо је потпуно супротно, } \\
\text { потпуни контраст }\end{array}$ & $\begin{array}{l}\text { Није ли познато да су цели сабори отаца проклетству и анатеми предали } \\
\text { оне који ће веровати да се находе андиподи? (139) }\end{array}$ \\
\hline архимидандрит м & $\begin{array}{l}\text { највиши свештенички чин монашког } \\
\text { реда, старешина манастира у пра- } \\
\text { вославној цркви }\end{array}$ & $\begin{array}{l}\text { У исти дан било је по обичају „умовеније ног” и служили су с митрополи- } \\
\text { том множество архимандрита и игумана. (126) } \\
\text { Ја ти више желим да у једном малом сеоцу будеш мале деце учитељ, него } \\
\text { у Хопову игуман или архимандрит. (132) }\end{array}$ \\
\hline \multicolumn{3}{|l|}{ Б } \\
\hline без м & платно & $\begin{array}{l}\text { Сутрадан, видећи да нећу нипошто више да закашњавам, метнула ми је у } \\
\text { торбу неколико танка беза за пар кошуља...(110) }\end{array}$ \\
\hline безмолвни, -а, -о & ћутљив, тих, без речи & ...уједињен у ком безмолвном месту ходам... (56) \\
\hline
\end{tabular}




\section{ЛИТЕРАТУРА}

Андрић 1976: Д. Андрић, Речник жаргона - двосмерни речник српског жаргона и жаргону сродних речи и израза, Београд: БИГЗ.

Вујаклија 1991: М. Вујаклија, Лексикон страних речи и израза, Београд: Просвета.

Клајн 1992: И. Клајн, Речник нових речи, Нови Сад: Матица српска.

Клајн/Шипка 2008: И. Клајн, М. Шипка, Велики речник страних речи и израза, Нови Сад: Прометеј.

Мркаљ 2008: 3. Мркаљ, Наставно проучавање народних приповедака и предања, Београд: Друштво за српски језик и књижевност Србије.

Мршевић Радовић 2008: Д. Мршевић-Радовић, Фразеологија и национална култура, Београд: Друштво за српски језик и књижевност Србије.

Николић 2009: М(илија) Николић, Методика наставе српског језика и књижевности, Београд: Завод за уџбенике.

Николић 2000: М(ирослав) Николић, Обратни речник српскога језика, Нови Сад: Матица српска. Београд: Институт за српски језик САНУ, Палчић.

Нушић 2001: Б. Нушић, Аутобиографија, Београд: Креативни центар.

Обрадовић 1969: Д. Обрадовић, Изабрани списи, Српска књижевност у сто књига, књига 10, Нови Сад-Београд: Матица српска, Српска књижевна задруга, стр. 67-82, 109-144.

Општи стандарди постигнућа за крај општег средњег и средњег стручног образовања и васпитања у делу општеобразовних предмета, за предмет Српски језик и кьижевност 2015.

PJA3У: Rječnik hrvatskoga ili srpskoga jezika, Zagreb: Jugoslavenska akademija znanosti i umjetnosti, 1880-1976.

PMC: Речник српскохрватскога књижевног језика I - VI, Нови Сад (Загреб): Матица српска (и Матица хрватска), 1967-1976.

РСАНУ: Речник српскохрватског книжевног и народног језика САНУ, I-XIX, Београд: Српска академија наука и уметности - Институт за српски језик, 1959-.

PCJ: Речник српскога језика, Нови Сад: Матица српска, 2007.

Стефановић/Пипер/Драгићевић 2011: М. Стефановић, П. Пипер, Р. Драгићевић, Обратни асочијативни речник српскога језика, Београд: Службени гласник - Београдска књига.

Ћирилов 1991: Ј. Ћирилов, Нови речник нових речи. Речи, изрази и значења преузети из других језика или настали у српскохрватском језику после Другог светског рата, Београд: Бата.

Цвијетић 2005: Р. Цвијетић, Речници у настави српског језика и књижевности. Приручник за наставнике, Београд: Завод за уџбенике и наставна средства. 


\section{WAYS TO USE THE DICTIONARY OF SERBIAN LANGUAGE TEACHING SERBIAN LANGUAGE AND LITERATURE}

\section{Summary}

The paper discusses which of the dictionaries of the Serbian language are recommended for the use of teaching Serbian language and literature.

It points to the different uses of vocabulary: a) in regular classes of literature, with the help of methodical action, the interpretation of the unknown and less known words and phrases when interpreting literary and artistic texts; b) in the regular language teaching, with specific teaching units, for example: histories, archaisms, neologisms, colloquialisms ...; v) in the work of the linguistic section - based on the example of existing vocabularies, students create dictionaries on specific topics (e.g. Dictionary of unknown and less known words foe the piece Zivot i prikljucenija, Dositej Obradović); g) at oral and written expression classes, with the aim of further enriching the student dictionary; d) in improving the reading and understanding skills of the reader, where special attention is paid to the context and versatility of individual words, as well as to their stylistic role; đ) in Serbian language classes in the school library - where students are directly introduced to the appearance and different types of vocabulary, as well as to the way they are used.

Keywords: dictionaries, teaching, Serbian language, literature, unknown words, linguistic section, school library. 